\title{
ACCase-inhibiting herbicides: mechanism of action, resistance evolution and stewardship
}

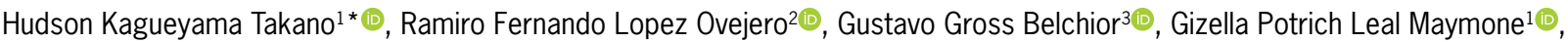 \\ Franck E. Dayan ${ }^{1} 10$
}

${ }^{1}$ Colorado State University-Bioagricultural Sciences and Pest Management, 300 W Pitkin St. - 80521 - Fort Collins, CO - USA.

²Bayer Crop Science, Av. das Nações Unidas, 12901 04578-000 - São Paulo, SP - Brasil.

${ }^{3}$ Core Us Comunicação Científica, R. Tuim, 762 - 04514-103

- São Paulo, SP - Brasil.

*Corresponding author <hudson.takano@colostate.edu>

Edited by: Paulo Cesar Sentelhas

Received April 17, 2019

Accepted June 09, 2019
ABSTRACT: Herbicides play an important role in preventing crop yield losses due to both their weed interference ability and their capacity for increasing soil conservation in no-till systems. Group A herbicides or acetyl-CoA carboxylase (ACCase) are essential tools the selective management of glyphosate resistance in grass weed species. In this review, we describe important aspects of ACCase biology and herbicides targeting this enzyme, along with a discussion on stewardship programs to delay the evolution of herbicide resistance which can evolve either through target site and/or non-target site mechanisms. Sixteen-point mutations have been reported to confer resistance to ACCase inhibitors. Each mutation confers cross resistance to a different group of herbicides. Metabolic resistance can result in resistance to multiple herbicides with different mechanisms of action (MoA), and herbicide detoxification is often conferred by cytochrome P450 monooxigenases and glutathione-Stransferases. Regardless of whether resistance mechanisms are target or non-target site, using herbicides with the same MoA will result in resistance evolution. Therefore, while field surveys and resistance mechanism studies are crucial for designing reactive management strategies, integrated weed management plays a central role in both reactive and proactive mitigation of herbicide resistance evolution.

Keywords: herbicide resistance, integrated weed management, aryloxyphenoxypropionates, cyclohexanediones, phenylpyrazoline

\section{Introduction}

The world population has grown over the past few decades and is estimated to reach 9.7 billion people in 2050 (Gerland et al., 2014). As the population continues to grow, agriculture technologies need to increase crop yields to meet the ever-increasing demand for food (Tester and Langridge, 2010). South America is a major food producer in the global agriculture chain, encompassing approximately $25 \%$ of the world's total cultivated area with cotton, corn, and soybean, representing 1.7,23.0, and 62.1 million ha, respectively (USDA, 2018). Weeds are one of the greatest challenges to modern agriculture causing, on average, a $35 \%$ reduction in crop yield (Oerke, 2006). Herbicides are extremely efficient tools for weed management and have been a key component to maintain no-till systems in agriculture (Naylor, 2008).

Group A herbicides or acetyl-CoA carboxylase (ACCase) inhibitors were first introduced into the market in 1978 (Kaundun, 2014) with the appearance of diclofop-methyl. These herbicides provide selective grass weed control in dicot crops and a limited number of active ingredients for use in monocot crops with an estimated treated area of 120 million ha per year (Busi et al., 2018). ACCase-inhibiting herbicides play a key role in managing glyphosate-resistant (GR) grasses, one of the greatest weed management challenges facing South America (Lopez Ovejero et al., 2017). This manuscript covers a detailed review of important aspects related to ACCase inhibitors along with best stewardship practices for herbicide resistance management.

\section{ACCase and its physiological function}

Fatty acids are carboxylic acids with long aliphatic chains that perform important physiological functions (e.g. energy storage, cell/organelle membrane structure composition, hormonal regulation) in living organisms. The ubiquitous, biotin-dependent ACCase enzyme catalyzes two irreversible reactions that determine commitment to the fatty acid synthesis pathway (Dayan et al., 2019). The enzyme consists of three functional domains: biotin-carboxyl carrier protein (BCCP), biotin carboxylase $(\mathrm{BC})$, and carboxyltransferase $(\mathrm{CT}$, with subunits $\alpha$ and $\beta$ ) (Figure 1). The BC and CT domains shoulder the catalytic activities that are dependent upon ATP, $\mathrm{Mg}^{2+}$, and $\mathrm{HCO}_{3}^{-}$, which result in acetylCoA carboxylation and the formation of malonyl-CoA. The two reactions catalyzed by the $\mathrm{BC}$ and $\mathrm{CT}$ subunits are presented, respectively, below (Nikolau et al., 2003; Sasaki and Nagano, 2004; Shorrosh et al., 1994):

$(\mathrm{BC}) \mathrm{BCCP}+\mathrm{HCO}_{3}^{-}+\mathrm{Mg}^{2+}+\mathrm{ATP} \rightarrow \mathrm{BCCP}+\mathrm{CO}_{2}+$ $\mathrm{Mg}^{2+}+\mathrm{ADP}+\mathrm{Pi}$

(CT) $\mathrm{BCCP}+\mathrm{CO}_{2}+$ Acetyl-CoA $\rightarrow \mathrm{BCCP}+\mathrm{CO}_{2}+$ $\mathrm{Mg}^{2+}+\mathrm{ADP}+\mathrm{Pi}^{2+}$

While malonyl-CoA is necessary for de novo synthesis of fatty acids in plastids, cytosolic malonyl$\mathrm{CoA}$ is required for the elongation of very long chain fatty acids (VLCFAs) and secondary metabolites such as flavonoids and suberins (Harwood, 1988). Plants express plastidic and cytoplasmic ACCase isoforms. The plastidic isoform is responsible for more than $80 \%$ of total ACCase 


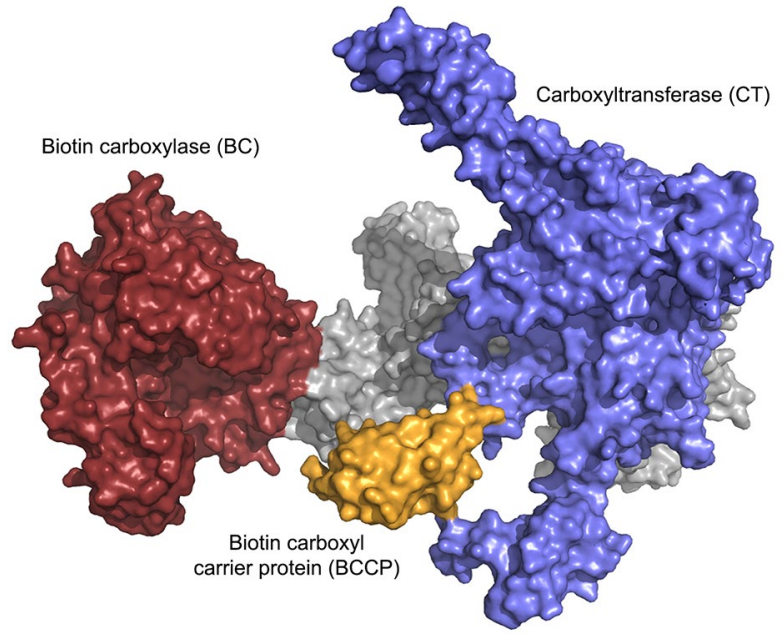

Figure 1 - A tertiary structure view of wheat (T. aestivum) eukaryotic ACCase and its domains: biotin carboxylase (BC), biotin carboxyl carrier protein (BCCP), and carboxyltransferase (CT).

activity in leaves (Egli et al., 1993; Ashton et al., 1994; De Prado et al., 2004). Plants belonging to the Poaceae family (grasses), possess a homomeric (or eukaryotic) plastidic ACCase in which the BCCP, BC, and CT domains are localized within a single polypeptide chain (Incledon and Hall, 1997). Both plastidic and cytoplasmic ACCase in Poaceae become active when homodimerized (Egli et al., 1993; Zhang et al., 2003). Dicotyledonous plants have homomeric form in the cytoplasm and heteromeric (or prokaryotic) form in the plastids, where each domain is encoded by different genes expressed in a coordinated fashion (Sasaki and Nagano, 2004).

\section{ACCase-inhibiting (Group A) herbicides Classification and general characteristics}

ACCase-inhibitingor Group A herbicidesaredivided into three chemical families: aryloxyphenoxypropionates (FOPs), cyclohexanodiones (DIMs), and phenylpyrazole (DENs). While FOPs and DIMs were introduced over 45 years ago, DEN was launched in 2006 and consists of a single herbicide, pinoxaden (Hofer, 2006; Dayan et al., 2019). All molecules belonging to these chemical groups consist of a carbon skeleton with polar substituents, but structures presenting distinct characteristics (Délye, 2005). Most FOPs are in the form of formulated methyl, butyl or ester, providing more lipophilicity and increased capacity to cross cellular membranes by acid trapping (Takano et al., 2019b). These herbicides have a molecular weight of between 327 and $400 \mathrm{~g} \mathrm{~mol}^{-1}$, pKa of 3.5-4.1 in their weak acid form and Log $\mathrm{K}_{\text {ow }}$ of 3.6-4.2 in the formulated form (Shaner, 2014).

The three classes of ACCase-inhibiting herbicides have limited residual activity in the soil. This is attributed to their high values of solid-liquid partition $\left(\mathrm{K}_{\mathrm{d}}\right)$ and adsorption potential $\left(\mathrm{K}_{\mathrm{oc}}\right)$, resulting in herbicide molecules becoming tightly bound to soil particles.
However, once in the soil, these herbicides can be converted to their acid form, and be absorbed by plant roots and cause damage. The potential for carryover varies from one species to another, soil characteristics, and herbicide dosage, but residual activity was not observed for more than 14 days (Lancaster et al., 2018).

\section{Mechanism of action (MoA)}

ACCase-inhibiting herbicides have specific activity on grasses due to their selective inhibition of homomeric plastidic ACCase which is only found in monocots, with exceptions. Neither heteromeric plastic nor homomeric cytosolic forms are inhibited by ACCase inhibitors, making dicots tolerant to them (Kukorelli et al., 2013). Exceptions include susceptible Geraniaceae species and a few Brassica and Arabidopsis species (Kaundun, 2014) expressing the homomeric ACCase in their chloroplasts.

These herbicides halt ACCase activity by blocking fatty acid biosynthesis, preventing the formation of lipid and secondary metabolites in susceptible plants. This results in a loss of cell membrane integrity, metabolite leakage, and ultimately cell death (Délye, 2005; Kaundun, 2014). This process begins when the herbicide is absorbed by the leaves and translocates to proliferating meristematic tissues through the phloem where it damages the cell membrane structure, inhibits meristematic activity, and restricts the growth of new leaves (Kukorelli et al., 2013). Necrotic symptoms can be observed in growing tissues after one week of application, with initial chlorosis and subsequent disintegration of the leaves (Dayan et al., 2019). The efficacy of these herbicides is positively correlated with higher relative air humidity due to an increase in molecule uptake and translocation in the plant (Cieslik et al., 2013). Studies of enzyme kinetics have shown that FOPs and DIMs are non-competitive inhibitors of ATP $\mathrm{Mg}^{2+}$, and $\mathrm{HCO}_{3}^{-}$, but are competitive inhibitors of acetyl-CoA substrate. This suggests they act by inhibiting the transcarboxylation step (CT domain) rather than the biotin carboxylation step (BC domain) despite binding to the same catalytic site in the CT domain (Rendina et al., 1990; Burton et al., 1991; Burton, 1997; Devine, 2002).

Molecular and biochemical data have clearly established that the CT domain in the homomeric ACCase bears the target binding site of FOPs, DIMs, and DEN (Délye, 2005; Xia et al., 2016) even though they bind in distinct regions of the homodimer interface. Crystal structure analyses of Staphylococcus aureus CT domain in complex with at least one herbicide from each group showed that the molecules shared two common anchoring points (Ile1735 and Ala1627) with the yeast CT domain regardless of discrepancies in their chemical structures (Xia et al., 2016) (Figure 2A and B).

Results from a computational simulation of Setaria italica CT domain in complex with ACCase inhibitors suggested that these herbicides can also form a hydrogen bond with binding site at residue Ser698 (Zhu et al., 2006). For one specific FOP (metanifop) residue 

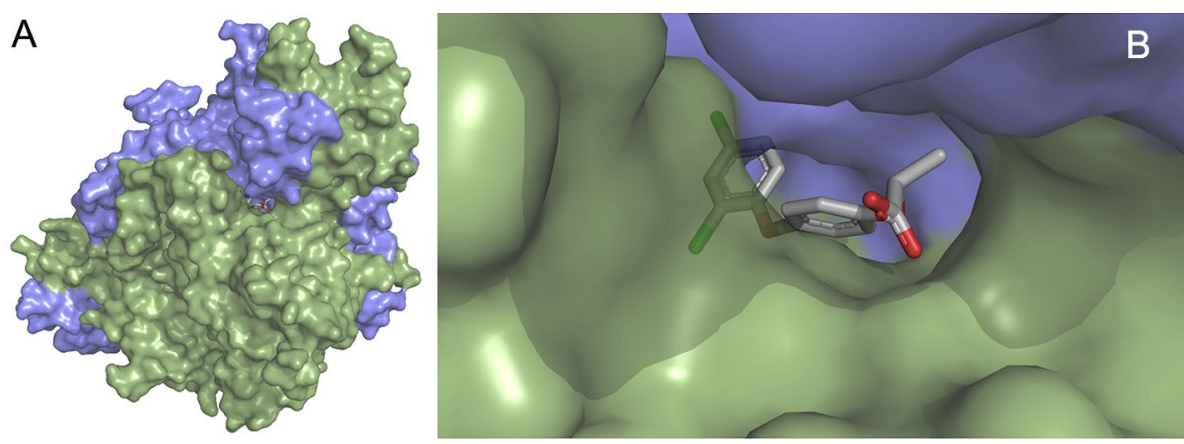

Figure 2 - Crystal structure of the carboxyltransferase (CT) domain of yeast ACCase in complex with the herbicide diclofop (A). A closer view of diclofop within the binding domain formed at the interface of the dimerized CT structure (B). Adapted from 1UYR (Zhang et al., 2004).

Thr194 was essential to the interacting and binding to the CT domain (Xia et al., 2016). Furthermore, kinetic analyses suggested FOPs and DIMs present double inhibition, i.e. the binding of one of these herbicide classes prevents the binding of molecules from the other (Rendina et al., 1990). Finally, studies with pinoxaden showed this molecule has a very similar binding site to tepraloxydim, a DIM herbicide, despite considerable differences in their chemical structures (Yu et al., 2010; Kaundun, 2014). Not only do these findings suggest the wide variety of molecular mechanisms that underlie CT domain inhibition, but also shed light on the importance of elucidating the molecular basis for target and crossresistance among ACCase-inhibiting herbicides (Xia et al., 2016).

\section{Mechanisms of weed resistance to ACCase inhibitors}

Weeds resistance to ACCase inhibitors have significant economic relevance especially due to the limited number of herbicides with alternative MoAs, and their role in managing GR monocot weeds in postemergence. Resistant biotypes may evolve after six to ten years of selective pressure by ACCase inhibitors, particularly in crop systems in which the application of these herbicides is used as the only form of grass weed management tool (Devine, 2002). The high initial frequency $\left(6 \times 10^{-10}\right.$ plants $)$ of resistant biotypes also significantly affects resistance evolution (Vidal and Fleck, 1997). The first case of resistance to ACCase inhibitors was reported in 1982, only four years after their introduction into the market, in Lolium rigidum from a wheat field in Australia (Heap and Knight, 1982). To date, 48 resistant species have been reported worldwide (Heap, 2019). In Australia, resistance to pinoxaden was reported for $L$. rigidum populations even before the herbicide was launched in 2006 as shown in studies from 2003 and 2005 (Boutsalis et al., 2012). Likewise, target site mutations were found in herbarium specimens of the grass weed Alopecurus myosuroides, which were collected between 1788 and 1975, prior to the commercial release of herbicides inhibiting ACCase
(Délye et al., 2013). This evidence suggests that point mutations causing resistance to ACCase inhibitors evolve from standing genetic variation in weed populations, rather than de novo mutations in wild-type genotypes.

In South America, populations of eight weed species have been reported with resistance to ACCase inhibitors: Sorghum halepense (Johnsongrass - also resistant to glyphosate), Urochloa plantaginea (alexandergrass), Digitaria ciliaris (southern crabgrass), Eleusine indica (indian goosegrass - also resistant to glyphosate), Avena fatua (wild oat), Lolium multiflorum (ryegrass - also resistant to glyphosate or ALS inhibitors), Echinochloa crus-galli (barnyardgrass) and Digitaria insularis (sourgrass - also resistant to glyphosate) (Heap, 2019). As is the case for other herbicides and MoAs, weed biotypes resistant to ACCase inhibitors can evolve from target site resistance or non-target site resistance.

\section{Target site resistance (TSR)}

Resistance cases directly associated with the ACCase enzyme can emerge from mutations or increased enzyme expression levels (Figure 3). The affinity of herbicides to enzymes is one of the properties that determine herbicide efficacy (Dayan et al., 2010; Dayan et al., 2015). Physicochemical interactions are among the main factors determining the affinity for a ligand (e.g. herbicide) to an enzyme. In the case of ACCaseinhibiting herbicides, the interactions between the active ingredient (FOPs, DIMs, or DEN) and the amino acids in specific positions of the polypeptide chain on ACCase CT domain define affinity and inhibitor efficacy (Figure $2 \mathrm{~A}$ and $\mathrm{B})$. Thus, a single nucleotide polymorphism (mutation) in the ACCase gene can result in amino acid substitutions imparting resistance to herbicides.

The genetic determinants and associated fitness costs are well known for weeds resistant to ACCaseinhibiting herbicides (Colbach et al., 2016). Mutations in the plastidic ACCase gene resulting in enzyme primary sequence modifications have been the subject of research for over a decade and are well characterized (Délye, 2005). Sixteen such alterations have been described so far and most notably observed at amino 


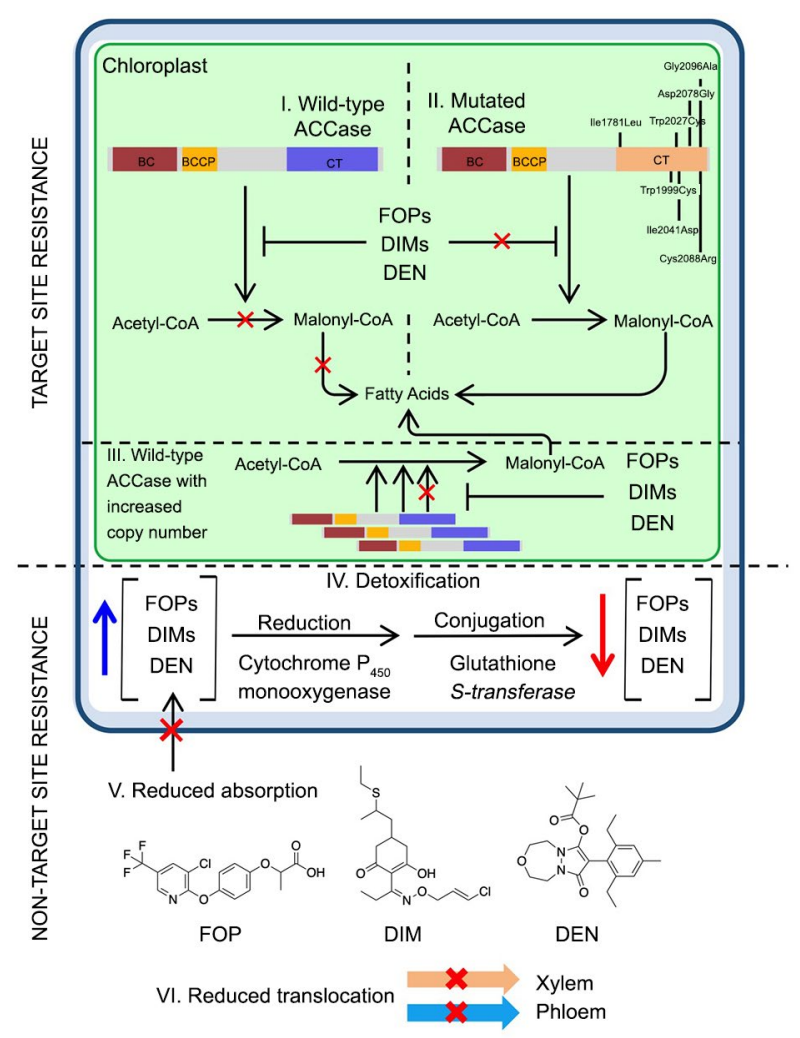

Figure 3 - Main aspects of acetyl-coenzyme A carboxylase (ACCase)-inhibiting herbicide resistance in grasses and different ways by which resistance can evolve. (I) interaction between ACCase inhibitors and a wild type enzyme; (II) resistance by ACCase mutations or (III) wild type ACCase increased copy number; (IV) metabolic resistance by herbicide detoxyfication, (V) reduced absorption, or $(\mathrm{VI})$ reduced translocation. $\mathrm{BC}=$ biotin carboxylase, $\mathrm{BCCP}=$ biotin carboxyl carrier protein; $\mathrm{CT}$ = carboxyltransferase; FOP = aryloxyphenoxypropionates; DIM = cyclohexanedione; DEN $=$ phenylpyrazolin.

acid positions 1781,2027, 2041, 2078, and 2096 of the polypeptide chain, but also occur at positions 1999 and 2088 (Heckart et al., 2008; Kaundun, 2010; Beckie et al., 2012; Kaundun et al., 2012; Kaundun et al., 2013). Target site mutation in grass species commonly present in South America have been reported in other parts of the world (Table 1). Unfortunately, only a very limited number of weeds resistant to ACCase inhibitors in South America have had the resistance mechanism elucidated such as E. indica (Osuna et al., 2012).

Cross-resistance to herbicides that act under the same MoA is usually caused by TSR mechanisms (Beckie et al., 2012; Chen et al., 2017), even though recent evidence indicates the importance of NTSR in conferring cross-resistance (Iwakami et al., 2019). Several authors have reported weeds manifesting crossresistance to different ACCase-inhibiting herbicides, including those arising from mutations Ile1781Leu,
Ile2041Asn, and Trp2027Cys (Chen et al., 2017). In addition to the mutations Asp2078Gly and Cys2088Arg conferring broad spectrum of resistance on all classes of ACCase-inhibiting herbicides (Yu et al., 2007; Délye et al., 2008; Kaundun, 2010; Scarabel et al., 2011; CruzHipolito et al., 2011; Gherekhloo et al., 2012; Osuna et al., 2012; Kaundun et al., 2012), resistance levels are not solely dependent upon amino acid substitutions. Allele number and initial frequency, recessive and dominant allele interactions, weed species, plant growth stage, herbicide recommended dose, and other factors also influence herbicide resistance levels (Kaundun, 2014).

This implies that the same mutation may result in contrasting herbicide sensitivity phenotypes when different species are compared. This is the case of Ile2041Asn, a mutation that results in a cycloxydimresistant biotype in Phalaris paradoza but not in Alopecurus myosuroides (Délye et al., 2008; Hochberg et al., 2009). Homozygosity levels determined L. rigidum control with clethodim in a field in Australia where the recommended doses were efficient against heterozygous Ile1781Leu plants but not homozygous plants (Yu et al., 2007). Furthermore, ACCase gene mutation frequencies naturally vary with species, site, and the geography of herbicide selection pressure (Délye et al., 2010). Pleiotropy also affects resistance dynamics in a population and should be considered for establishing prediction models and recommendations towards best management practices aimed at delaying eventual mutation-related resistance cases (Colbach et al., 2016).

Selection pressure imposed by ACCase-inhibiting herbicides can lead to increased enzyme-specific activity (higher [enzyme activity: total protein mass] ratio) due to a higher protein expression rate. ACCase overexpression allows for sustained fatty acid synthesis rates under the same herbicide concentrations that would normally inhibit catalysis as the active ingredient no longer blocks the enzyme physiological role at rates incompatible with cellular metabolism. Reported cases include Sorghum halepense in the US (Bradley et al., 2001), Leptochloa chinensis in Thailand (Pornprom et al., 2006), and E. indica in Malaysia (San Cha et al., 2014). Importantly, increased protein expression rates may be associated with ACCase mutations (San Cha et al., 2014) and should be considered in the context of an integrated weed management approach.

\section{Non target site resistance (NTSR)}

Non target site resistance has gained attention as an emerging resistance mechanism to ACCase-inhibiting herbicides (Kaundun, 2014). This type of resistance encompasses a range of processes, including enhanced metabolism, herbicide detoxification, and reduced uptake and translocation (Powles and Yu, 2010; Kukorelli et al., 2013; Kaundun, 2014). Resistance levels resulting from these processes are relatively low when compared to TSR and plants may be controlled if treated at early growth stages. In addition, NTSR is often present in 
Table 1 - Reported mutations in ACCase associated with resistance to different classes of Group A herbicides in grass species commonly present in South American fields.

\begin{tabular}{|c|c|c|c|}
\hline Substitution & Species & Resistance to & Reference \\
\hline \|le1781Leu & Lolium multiflorum & $\begin{array}{l}\text { Clodinafop } \\
\text { Haloxyfop } \\
\text { Sethoxydim } \\
\text { Pinoxaden } \\
\text { Clethodim (low level) }\end{array}$ & (Powles and Yu, 2010; Scarabel et al., 2011; Kukorelli et al., 2013) \\
\hline Trp1999Cys & Lolium perenne & Fenoxaprop only & (Powles and Yu, 2010; Kukorelli et al., 2013; Xu et al., 2014) \\
\hline Trp2027Cys & Eleusine indica & $\begin{array}{l}\text { Fenoxaprop } \\
\text { Clodinafop } \\
\text { Pinoxaden }\end{array}$ & (Powles and Yu, 2010; Kukorelli et al., 2013; San Cha et al., 2014) \\
\hline Trp2027Cys & Digitaria insularis & $\begin{array}{l}\text { Haloxyfop } \\
\text { Quizalofop } \\
\text { Fenoxaprop } \\
\text { Pinoxaden }\end{array}$ & (Takano et al., 2020) \\
\hline Ile2041Asn/Nal & Lolium rigidum & $\begin{array}{l}\text { Clodinafop } \\
\text { Haloxyfop } \\
\text { Pinoxaden (low level) }\end{array}$ & (Powles and Yu, 2010; Scarabel et al., 2011; Kukorelli et al., 2013) \\
\hline Ile2041Asn & Sorghum halepense & $\begin{array}{l}\text { Fluazifop } \\
\text { Propaquizafop } \\
\text { Quizalofop } \\
\text { Haloxyfop }\end{array}$ & (Powles and Yu, 2010; Kukorelli et al., 2013; Scarabel et al., 2014) \\
\hline Asp2078Gly & Lolium multiflorum & $\begin{array}{l}\text { Diclofop } \\
\text { Sethoxydim } \\
\text { Clethodim } \\
\text { Pinoxaden }\end{array}$ & (Kaundun, 2010; Powles and Yu, 2010; Kukorelli et al., 2013) \\
\hline Asp2078Gly & Avena fatua & $\begin{array}{l}\text { Diclofop } \\
\text { Fenoxaprop } \\
\text { Cyhalofop } \\
\text { Propaquizafop } \\
\text { Clethodim } \\
\text { Cycloxydim } \\
\text { Pinoxaden }\end{array}$ & (Powles and Yu, 2010; Cruz-Hipolito et al., 2011; Kukorelli et al., 2013) \\
\hline Asp2078Gly & Eleusine indica & $\begin{array}{l}\text { Fluazifop } \\
\text { Haloxyfop } \\
\text { Cyhalofop } \\
\text { Sethoxydim } \\
\text { Clethodim } \\
\text { Tepraloxydim }\end{array}$ & (Powles and Yu, 2010; Osuna et al., 2012; Kukorelli et al., 2013) \\
\hline Cys2088Arg & Lolium rigidum & $\begin{array}{l}\text { Clodinafop } \\
\text { Haloxyfop } \\
\text { Sethoxydim } \\
\text { Clethodim } \\
\text { Pinoxaden }\end{array}$ & (Powles and Yu, 2010; Scarabel et al., 2011; Kukorelli et al., 2013) \\
\hline Gly2096Ala & Avena fatua & $\begin{array}{l}\text { Clodinafop } \\
\text { Fenoxaprop } \\
\text { Diclofop } \\
\text { Haloxyfop } \\
\text { Sethoxydim (low level) }\end{array}$ & (Délye, 2005; Powles and Yu, 2010; Beckie et al., 2012; Kukorelli et al., 2013) \\
\hline
\end{tabular}

populations that already contain one of the TSR alleles, such as in Lolium rigidum (Han et al., 2016).

Detoxification occurs when herbicide metabolism rates increase, and the active ingredient is modified into a non-toxic molecule by oxidation, hydrolysis, or reduction (phase 1). Subsequently, metabolites are combined with a glutathione tripeptide, a sugar molecule, or an amino acid (phase 2) (Délye, 2005). Therefore, toxic component concentration decreases to an extent that is no longer capable of inhibiting vital metabolic pathways. Resistant biotypes are characterized by increased expression levels of enzymes involved in herbicide metabolism, in particular, those of cytochrome P450 monooxygenase enzymes (phase 1) and glutathione-S-transferase (phase 2) (Brazier et al., 2002; Kaundun, 2014). Glucosyl-S- transferase causes herbicide conjugation and its gene is typically upregulated in herbicide-resistant weeds (Yu and Powles, 2014). Cases associated with cytochrome P450-mediated enhanced metabolism have been widely reported (Fernández et al., 2016) and confirmed in different weed species such as Avena spp., E. phyllopogon and L. rigidum (Menendez and De Prado, 1996; De Prado et al., 2005; Bakkali, 2007; Ahmad-Hamdani et al., 2012). Moreover, a recent report found the existence of temperature-dependent pinoxaden resistance in Brachypodium hybridum, proposing that the oxidation and glucose conjugation biochemical pathways are significantly increased under the combination of pinoxaden application and high temperatures (Matzrafi et al., 2017). 
A large number of genes are clearly involved in the mechanisms that relate to NTSR and in many weed species, cytochrome P450 monooxygenase, glutathioneS-transferase and glucosyl transferase enzymatic activities are associated with multiple resistance (Délye, 2005; Powles and Yu, 2010). It is noteworthy that crossand multiple-resistance patterns associated with NTSR are often unpredictable, considering that resistance is conferred by metabolization rates of specific herbicides by those enzymes, regardless of their MoA. Consequently, weed management strategies based on the herbicide rotation with different MoAs becomes an inappropriate approach to mitigate resistance (Yu and Powles, 2014; Fernández et al., 2016). For example, an L. rigidum population with cytochrome P450-related increased metabolism is resistant to herbicides with distinct MoAs, including photosystem II, ALS, ACCase, and microtubule inhibitors (Preston and Powles, 2002; Powles and $\mathrm{Yu}, 2010)$.

Most cross-resistance studies in grass weeds to FOPs/DIMs/DEN report TSR and consequent reduction in ACCase sensitivity to these herbicides as the underlying cause (Yu et al., 2007; Kaundun, 2014; Chen et al., 2017). A number of reports have emphasized the need to better understand and elucidate the mechanisms of NTSR-based cross-resistance, considering that it is a threat to global crop production (Yu and Powles, 2014; Shergill et al., 2017; Iwakami et al., 2019). A recent study with a multiple resistant E. phyllopogon biotype on the three classes of ACCase inhibitors suggests the existence of a single trans element responsible for the overexpression of two genetically unlinked cytochrome P450 genes, CYP81A12 and CYP81A21. This finding supports the idea that NTSR can lead to cross-resistance to multiple herbicides due to the activation of $\mathrm{P} 450$ s that can even metabolize different classes of herbicides, such as ACCase and ALS inhibitors (Iwakami et al., 2019). Nonetheless, NTSR mechanisms still require additional investigation as their molecular basis remains, as yet, unknown.

Stewardship and herbicide resistance management Since 2012 , over $96 \%$ of soybean cultivated in South America has been genetically engineered for glyphosateresistance (Peterson et al., 2018). The overreliance on a single MoA and the absence of herbicide rotation and mixtures have contributed to the evolution of GR weeds (Takano et al., 2019a). Glyphosate resistance has now spread across most soybean fields from South America and the magnitude of infestation is even greater for grasses. The estimated infested area with GR D. insularis, for instance, is estimated to exceed 20 million ha in Brazil (Lopez Ovejero et al., 2017). ACCase inhibitors are the main tools deployed to manage GR grass weeds such as D. insularis, L. multiflorum and E. indica (Yu et al., 2007; Gemelli et al., 2013; Takano et al., 2018). To date, 48 species have been reported as resistant to ACCase inhibitors in the world (Figure 4), and eight of them are in South America (Heap, 2019).

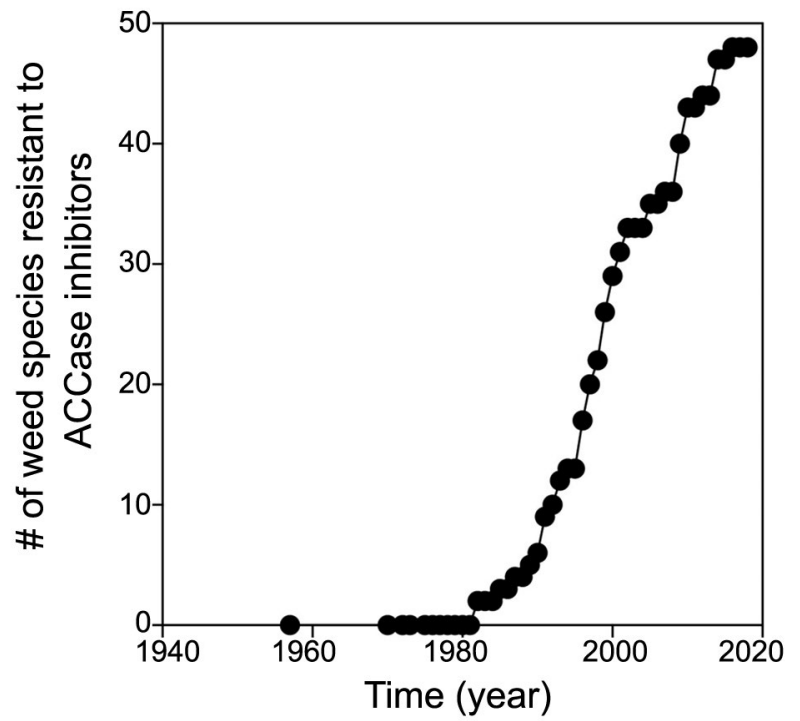

Figure 4 - Number of weed species with resistance to ACCaseinhibiting herbicides from 1970 to present. Adapted from http:// www.weedscience.org (Heap, 2019).

Clethodim is currently the most used ACCase herbicide in Brazil. This is because it generally provides better control over glyphosate-resistant $D$. insularis, compared to other ACCase-inhibiting herbicides (Gemelli et al., 2013). There is a very limited number of alternative herbicides to selectively control grasses in post-emergence. The upcoming traits for herbicide resistance in crops providing selective post-emergence grass control are Liberty Link soybean (glufosinateresistance) and Enlist corn (haloxyfop-resistance). This will probably increase the usage of FOP herbicides to control $D$. insularis in corn post-emergence. Therefore, it is crucial to establish stewardship strategies to avoid the evolution and spread of ACCase resistant populations.

Integrated weed management (IWM) is the combination of multiple weed control methods in order to reduce weed interference below the economic threshold level (Thill et al., 1991). IWM is becoming more and more critical for both reactive and proactive weed resistance management (Figure 5). Survey studies are critical to designing resistance management strategies through a more reactive approach (Beckie et al., 2000). Similarly, understanding herbicide resistance mechanisms is a key component in designing management strategies. For instance, as seen in Table 1 , certain mutations in ACCase confer resistance on one chemical family of herbicides but not on others. Therefore, even though rotating herbicides from different groups (FOP, DIM or DEN) could still be effective in the short term (depending on which mutation is involved), it cannot be recommended due to the rapid selection of cross resistance. For example, the mutation Trp2027Cys in Digitaria insularis (Takano et al., 2020) confers resistance to FOPs but not on DIMs. Therefore, 


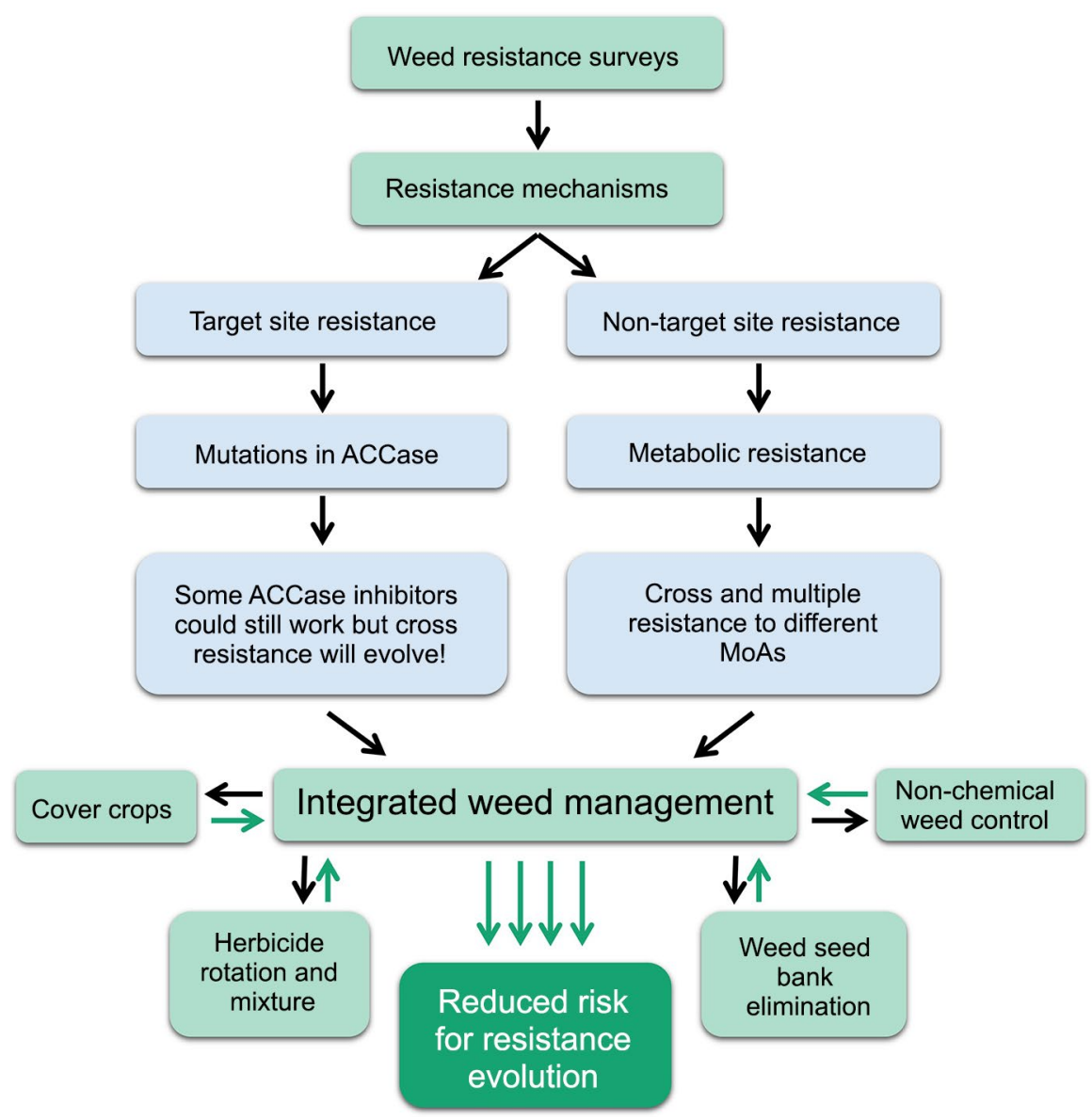

Figure 5 - The central role of integrated weed management (IWM) in avoiding or delaying herbicide resistance evolution. In a more reactive situation, IWM works as the only alternative to control weeds that have already evolved resistance (black arrows). In this case, weed resistance surveys and resistance mechanisms studies are crucial to design a management approach. On the other hand, an ideal situation, farmers can be more proactive avoiding or delaying the evolution of resistant weeds through IWM practices (green arrows).

using DIMs would still be an effective treatment but these herbicides should be used rationally and take into account other IWM practices. The inheritance mode of a resistance trait is also important in the designing of weed management strategies (Neve, 2007). If resistance is conferred by one single gene, resistant biotypes would be selected faster under high doses of herbicides $(\mathrm{Ng}$ et al., 2004). On the other hand, when resistance is inherited by multiple genes (e.g. metabolic resistance), low doses of herbicides allow the accumulation of resistance genes over generations (Neve and Powles, 2005). Unfortunately, there are still considerable gaps between research-based evidence and how weeds can be managed more efficiently to overcome herbicide resistance (Lamichhane et al., 2017).

When weeds evolve resistance to ACCase inhibitors, their management becomes more challenging due to the lack of alternative MoAs available for selective grass control in post-emergence. In addition, when resistance mechanisms involve herbicide metabolism, they can confer resistance to multiple herbicide MoAs (Busi et al., 2012). Therefore, herbicide resistance management should definitely not focus only on herbicides, but on a more proactive approach as part of the IWM program (Beckie et al., 2012). One of the most efficient goals within IWM is to focus on lowering the weed seed bank density as close as possible to zero (Norsworthy et al., 2012). The harvest weed seed control is a promising tool to destroy weed seeds at crop harvest, lowering the soil seed bank and adding one additional diversity level in weed control (Walsh et al., 2018). Likewise, the integration of herbicide rotation and mixture with cover crops such as Brachiaria ruziziensis is a successful example of integrated weed management to mitigate herbicide resistance (Marochi et al., 2018).

Best agronomic practices significantly contribute to integrated weed management. For instance, spraying herbicides under recommended doses and appropriate conditions (e.g. luminosity, relative humidity and temperature) are important to delay resistance evolution (Norsworthy et al., 2012). Likewise, application technology principles (e.g. appropriate nozzles, tractor 
speed, tank pressure, droplet size, use of surfactants, and spray volume) are essential to maximize efficacy and avoid NTSR selection by sub-doses (Busi et al., 2013). Mixing ACCase inhibitors with glyphosate generally enhances grass weed control even for glyphosate resistant species (Takano et al., 2018).

Resistance to ACCase inhibitors is still an emerging issue in South America; immediate attention and efforts are needed from several levels of the agricultural production chain (e.g. academia, industry, and government) (Powles and Gaines, 2016). All of these stakeholders collaborating with each other could provide efficient stewardship strategies to avoid losing efficacy of this important herbicide class. All existing tools for weed control, including both chemical and non-chemical approaches, should be considered by stewardship programs to preserve the efficacy of the technology. In addition, robust programs should fundamentally focus on educating growers to understand the importance of key practices and highlight the opportunity for greater crop yields in the long term.

\section{Final remarks}

A holistic strategy towards managing herbicideresistant weeds is crucial for agricultural sustainability and rising crop yield rates that will provide food, fibers, and energy to a growing population. ACCase-inhibiting herbicides are one of the most important tools to control GR grass species and prevent yield losses due to weed interference. Acquiring additional knowledge on the mechanisms behind both TSR and NTSR is key to designing mitigation strategies. Alternating or combining herbicides with different MoAs is valid provided that IWM tactics are well established and do not rule out other approaches that consider additional practices (e.g. no-till farming). Whichever tools are developed, they ought to be diverse enough to guarantee complementarity and assure that weeds not controlled by one single method will be targeted by the other(s). The future of agriculture is dependent on the synergy that needs to be created in the intersection of IWM, biotechnology, and stewardship.

\section{Authors' Contributions}

Conceptualization: Takano, H.K.; Lopez Ovejero, R.F.; Dayan, F.E. Data acquisition: Takano, H.K.; Lopez Ovejero, R.F.; Dayan, F.E.; Maymone, G.P.L.; Belchior, G.G. Writing and editing: Takano, H.K.; Lopez Ovejero, R.F.; Dayan, F.E.; Maymone, G.P.L.; Belchior, G.G.

\section{References}

Ahmad-Hamdani, M.S.; Yu, Q.; Han, H.; Cawthray, G.R.; Wang, S.F.; Powels, S.B. 2012. Herbicide resistance endowed by enhanced rates of herbicide metabolism in wild oat (Avena spp.). Weed Science 61: 55-62.
Ashton, A.R.; Jenkins, C.L.D.; Whitfeld, P.R. 1994. Molecular cloning of two different cDNAs for maize acetyl CoA carboxylase. Plant Molecular Biology 24: 35-49.

Bakkali, Y. 2007. Late watergrass (Echinochloa phyllopogon): mechanism involved in the resistance to fenoxaprop-Pethyl. Journal of Agricultural and Food Chemistry 55: 4052-4058.

Beckie, H.J.; Heap, I.M.; Smeda, R.J.; Hall, L.M. 2000. Screening for herbicide resistance in weeds. Weed Technology 14: 428445.

Beckie, H.J.; Warwick, S.I.; Sauder, C.A. 2012. Basis for herbicide resistance in Canadian populations of wild oat (Avena fatua). Weed Science 60: 10-18.

Boutsalis, P.; Gill, G.S.; Preston, C. 2012. Incidence of herbicide resistance in rigid ryegrass (Lolium rigidum) across southeastern Australia. Weed Technology 26: 391-398.

Bradley, K.W.; Wu, J.; Hatzios, K.K.; Hagood, E.S.J. 2001. The mechanism of resistance to aryloxyphenoxypropionate and cyclohexanedione herbicides in a johnsongrass biotype. Weed Science 49: 477-484.

Brazier, M.; Cole, D.J.; Edwards, R. 2002. O-Glucosyltransferase activities toward phenolic natural products and xenobiotics in wheat and herbicide-resistant and herbicide-susceptible black-grass (Alopecurus myosuroides). Phytochemistry 59: 149156.

Burton, J.D. 1997. Acetyl-coenzyme A carboxylase inhibitors. p. 187-205. In: Roe, M.R.; Burton, J.D.; Kuhr, R.J., eds. Herbicide activity: toxicology, biochemistry and molecular biology. IOs Press, Amsterdam, The Netherlands.

Burton, J.D.; Gronwald, J.W.; Keith, R.A.; Somers, D.A.; Gegenbach, B.G.; Wyse, D.L. 1991. Kinetics of inhibition of acetyl-coenzyme A carboxylase by sethoxydim and haloxyfop. Pesticide Biochemistry and Physiology 39: 100-109.

Busi, R.; Gaines, T.; Walsh, M.; Powles, S. 2012. Understanding the potential for resistance evolution to the new herbicide pyroxasulfone: field selection at high doses versus recurrent selection at low doses. Weed Research 52: 489-499.

Busi, R.; Goggin, D.E.; Heap, I.M.; Horak, M.J.; Jugulam, M.; Masters, R.A.; Napier, R.M.; Riar, D.S.; Satchivi, N.M.; Torra, J. 2018. Weed resistance to synthetic auxin herbicides. Pest Management Science 74: 2265-2276.

Busi, R.; Neve, P.; Powles, S. 2013. Evolved polygenic herbicide resistance in Lolium rigidum by low-dose herbicide selection within standing genetic variation. Evolutionary Applications 6: 231-242.

Chen, G.; Wang, L.; Xu, H.; Wu, X.; Pan, L.; Dong, L. 2017. Cross-resistance patterns to acetyl-CoA carboxylase inhibitors associated with different mutations in Japanese foxtail (Alopecurus japonicus). Weed Science 65: 444-451.

Cieslik, L.F.; Vidal, R.A.; Trezzi, M.M. 2013. Environmental factors affecting the efficacy of ACCase-inhibiting herbicides: a review. Planta Daninha 31: 483-489 (in Portuguese, with abstract in English).

Colbach, N.; Chauvel, B.; Darmency, H.; Délye, C.; Le Corre, V. 2016. Choosing the best cropping systems to target pleiotropic effects when managing single-gene herbicide resistance in grass weeds: a blackgrass simulation study. Pest Management Science 72: 1910-1925. 
Cruz-Hipolito, H.; Osuna, M.D.; Dominguez-Valenzuela, J.A.; Espinoza, N.; De Prado, R. 2011. Mechanism of resistance to ACCase-inhibiting herbicides in wild oat (Avena fatua) from Latin America. Journal of Agricultural and Food Chemistry 59: 7261-7267.

Dayan, F.E.; Barker, A.L.; Bough, R.; Ortiz, M.; Takano, H.K.; Duke, S.O. 2019. Herbicide mechanisms of action and resistance. p. 4826. In: Moo-Young, M., ed. Comprehensive biotechnology. Elsevier, Amsterdam, The Netherlands.

Dayan, F.E.; Duke, S.O.; Grossmann, K. 2010. Herbicides as probes in plant biology. Weed Science 58: 340-350.

Dayan, F.E.; Owens, D.K.; Corniani, N.; Silva, F.M.L.; Watson, S.B.; Howell, J.L.; Shaner, D.L. 2015. Biochemical markers and enzyme assays for herbicide mode of action and resistance studies. Weed Science 63: 23-63.

De Prado, J.L.; Osuna, M.D.; Heredia, A.; De Prado, R. 2005. Lolium rigidum, a pool of resistance mechanisms to ACCase inhibitor herbicides. Journal of Agricultural and Food Chemistry 53: 2185-2191.

De Prado, R.; Osuna, M.D.; Fisher, A.J. 2004. Resistance to ACCase inhibitor herbicides in a green foxtail (Setaria viridis) biotype in Europe. Weed Science 52: 506-512.

Délye, C. 2005. Weed resistance to acetyl coenzyme A carboxilase inhibitors: an update. Weed Science 53: 728-746.

Délye, C.; Deulvot, C.; Chauvel, B. 2013. DNA analysis of herbarium specimens of the grass weed Alopecurus myosuroides reveals herbicide resistance pre-dated herbicides. PloS ONE 8: e75117.

Délye, C.; Matéjicek, A.; Michel, S. 2008. Cross-resistance patterns to ACCase-inhibiting herbicides conferred by mutant ACCase isoforms in Alopecurus myosuroides Huds. (blackgrass), re-examined at the recommended herbicide field rate. Pest Management Science 64: 1179-1186.

Délye, C.; Michel, S.; Berard, A.; Chauvel, B.; Brunel, B.; Guillemin, J.P. 2010. Geographical variation in resistance to acetyl-coenzyme A carboxylase-inhibiting herbicides across the range of the arable weed Alopecurus myosuroides (blackgrass). New Phytologist 186: 1005-1017.

Devine, M.D. 2002. Acetyl-CoA carboxylase inhibitors. p. 103113. In: Hirai K.; Wakabayashi, K.; Boger P., eds. Herbicide classes in development: mode of action, targets, genetic engineering, chemistry. Springer, Berlin, Germany.

Egli, M.A.; Gegenbach, B.G.; Gronwald, J.W.; Somers, D.A.; Wyse, D.L. 1993. Characterization of maize acetyl-coenzyme A carboxylase. Plant Physiology 101: 499-506.

Fernández, P.; Alcántara-de la Cruz, R.; Cruz-Hipólito, H.; Osuna, M.D.; De Prado, R. 2016. Underlying resistance mechanisms in the Cynosurus echinatus biotype to acetyl CoA carboxylaseinhibiting herbicides. Frontiers in Plant Science 7: 449-455.

Gemelli, A.; Oliveira Junior, R.S.; Constantin, J.; Braz, G.B.P.; Campos Jumes, T.M.; Gheno, E.A.; Rios, F.A.; Franchini, L.H.M. 2013. Strategies to control of sourgrass (Digitaria insularis) glyphosate resistant in the out-of-season corn crop. Revista Brasileira de Herbicidas 12: 162-170 (in Portuguese, with abstract in English).

Gerland, P.; Raftery, A.E.; Ševčíková, H.; Li, N.; Gu, D.; Spoorenberg, T.; Alkema, L.; Fosdick, B.K.; Chunn, J.; Lalic, N. 2014. World population stabilization unlikely this century. Science 346: 234-237.
Gherekhloo, J.; Osuna, M.D.; De Prado, R. 2012. Biochemical and molecular basis of resistance to ACCase-inhibiting herbicides in Iranian Phalaris minor populations. Weed Research 52: $367-$ 372.

Han, H.; Yu, Q.; Owen, M.J.; Cawthray, G.R.; Powles, S.B. 2016. Widespread occurrence of both metabolic and target-site herbicide resistance mechanisms in Lolium rigidum populations. Pest Management Science 72: 255-263.

Harwood, J.L. 1988. Fatty acid metabolism. Annual Review of Plant Physiology and Plant Molecular Biology 39: 101-138.

Heap, I.; Knight, R. 1982. A population of ryegrass tolerant to the herbicide diclofop-methyl. Australian Journal of Agricultural Research 48: 156-157.

Heap, I.M. 2019. International survey of herbicide resistant weeds. Available at: http://www.weedscience.org [Accessed Apr 1, 2019]

Heckart, D.; Vencill, W.K.; Parrott, W.A.; Raymer, P.; Murphy, T.R. 2008. ACCase resistant large crabgrass (Digitaria sanguinalis) in Georgia. Paper presented at the 61st Southern Weed Science Society Annual Meeting, Jacksonville, FL.

Hochberg, O.; Sibony, M.; Rubin, B. 2009. The response of ACCase-resistant Phalaris paradoxa populations involves two different target site mutations. Weed Research 49: 37-46.

Hofer, U. 2006. Pinoxaden: for broad spectrum grass weed management in cereal crops. Journal of Plant Diseases and Protection 20: 989-995.

Incledon, B.J.; Hall, C.J. 1997. Acetyl-coenzyme A carboxylase: quaternary structure and inhibition by graminicidal herbicides. Pesticide Biochemistry and Physiology 57: 255-271.

Iwakami, S.; Kamidate, Y.; Yamaguchi, T.; Ishizaka, M.; Endo, M.; Suda, H.; Nagai, K.; Sunohara, Y.; Toki, S.; Uchino, A. 2019. CYP 81A P450s are involved in concomitant cross-resistance to acetolactate synthase and acetyl-CoA carboxylase herbicides in Echinochloa phyllopogon. New Phytologist 221: 2112-2122.

Kaundun, S.; Hutchings, S.-J.; Dale, R.; McIndoe, E. 2012. Broad resistance to ACCase inhibiting herbicides in a ryegrass population is due only to a cysteine to arginine mutation in the target enzyme. PloS ONE 7: e39759.

Kaundun, S.; Hutchings, S.-J.; Dale, R.P.; McIndoe, E. 2013. Role of a novel I1781T mutation and other mechanisms in conferring resistance to acetyl-CoA carboxylase inhibiting herbicides in a black grass population. PloS ONE 8: e69568.

Kaundun, S.S. 2010. An aspartate to glycine change in the carboxyl transferase domain of acetyl CoA carboxylase and non-target-site mechanism(s) confer resistance to ACCase inhibitor herbicides in a Lolium multiflorum population. Pest Management Science 66: 1249-1256.

Kaundun, S.S. 2014. Resistance to acetyl-CoA carboxylaseinhibiting herbicides. Pest Management Science 70: 14051417.

Kukorelli, G.; Reisinger, P.; Pinke, G. 2013. ACCase inhibitor herbicides: selectivity, weed resistance and fitness cost, a review. International Journal of Pest Management 59: 165-173.

Lamichhane, J.R.; Devos, Y.; Beckie, H.J.; Owen, M.D.; Tillie, P.; Messéan, A.; Kudsk, P. 2017. Integrated weed management systems with herbicide-tolerant crops in the European Union: lessons learnt from home and abroad. Critical Reviews in Biotechnology 37: 459-475. 
Lancaster, Z.D.; Norsworthy, J.K.; Scott, R.C. 2018. Residual activity of ACCase-inhibiting herbicides on monocot crops and weeds. Weed Technology 32: 364-370.

Lopez Ovejero, R.F.; Takano, H.K.; Nicolai, M.; Ferreira, A.; Melo, M.S.; Cavenaghi, A.L.; Christoffoleti, P.J.; Oliveira, R.S. 2017. Frequency and dispersal of glyphosate-resistant sourgrass (Digitaria insularis) populations across Brazilian agricultural production areas. Weed Science 65: 285-294.

Marochi, A.; Ferreira, A.; Takano, H.K.; Oliveira Junior, R.S.; Ovejero, R.F.L. 2018. Managing glyphosate-resistant weeds with cover crop associated with herbicide rotation and mixture. Ciência e Agrotecnologia 42: 381-394.

Matzrafi, M.; Shaar-Moshe, L.; Rubin, B.; Peleg, Z. 2017. Unraveling the transcriptional basis of temperature-dependent Pinoxaden resistance in Brachypodium hybridum. Frontiers in Plant Science 8: 1064-1071.

Menendez, J.; De Prado, R. 1996. Diclofop-methyl cross-resistance in a chlorotoluron-resistant biotype of Alopecurus myosuroides. Pesticide Biochemistry and Physiology 56: 123-133.

Naylor, R.E. 2008. Weed Management Handbook. Blackwell, Oxford, UK.

Neve, P. 2007. Challenges for herbicide resistance evolution and management: 50 years after Harper. Weed Research 47: 365369.

Neve, P.; Powles, S. 2005. Recurrent selection with reduced herbicide rates results in the rapid evolution of herbicide resistance in Lolium rigidum. Theoretical and Applied Genetics 110: 1154-1166.

Ng, C.-H.; Ratnam, W.; Surif, S.; Ismail, B.S. 2004. Inheritance of glyphosate resistance in goosegrass (Eleusine indica). Weed Science 52: 564-570.

Nikolau, B.J.; Ohlrogge, J.B.; Wurtele, E.S. 2003. Plant biotincontaining carboxylases. Archives of Biochemistry and Biophysics 414: 211-222.

Norsworthy, J.K.; Ward, S.M.; Shaw, D.R.; Llewellyn, R.S.; Nichols, R.L.; Webster, T.M.; Bradley, K.W.; Frisvold, G.; Powles, S.B.; Burgos, N.R. 2012. Reducing the risks of herbicide resistance: best management practices and recommendations. Weed Science 60: 31-62.

Oerke, E.C. 2006. Crop losses to pests. The Journal of Agricultural Science 144: 31-43.

Osuna, M.; Goulart, I.C.G.R.; Vidal, R.A.; Kalsing, A.; Ruiz Santaella, J.P.; De Prado, R. 2012. Resistance to ACCase inhibitors in Eleusine indica from Brazil involves a target site mutation. Planta Daninha 30: 675-681.

Peterson, M.A.; Collavo, A.; Ovejero, R.; Shivrain, V.; Walsh, M.J. 2018. The challenge of herbicide resistance around the world: a current summary. Pest Management Science 74: 2246-2259.

Pornprom, T.; Mahatamnuchoke, P.; Usui, K. 2006. The role of altered acetyl-CoA carboxylase in conferring resistance to fenoxaprop-P-ethyl in Chinese sprangletop [Leptochloa chinensis (L.) Nees]. Pest Management Science 62: 1109-1115.

Powles, S.B.; Gaines, T.A. 2016. Exploring the potential for a regulatory change to encourage diversity in herbicide use. Weed Science 64: 649-655.

Powles, S.B.; Yu, Q. 2010. Evolution in action: plants resistant to herbicides. Annual Review of Plant Biology 61: 317-347.
Preston, C.; Powles, S.B. 2002. Mechanisms of multiple herbicide resistance in Lolium rigidum. p. 150-160. In: Yamaguchi J.C.I., ed. Agrochemical resistance: extent, mechanism \& detection. Oxford University Press, New York, NY, USA.

Rendina, A.R.; Craig-Kennard, A.C.; Beaudoin, J.D.; Breen, M.K. 1990. Inhibition of acetyl-coenzyme A carboxylase by two classes of grass-selective herbicides. Journal of Agricultural and Food Chemistry 38: 1282-1287.

San Cha, T.; Najihah, M.G.; Sahid, I.B.; Chuah, T.S. 2014. Molecular basis for resistance to ACCase-inhibiting fluazifop in Eleusine indica from Malaysia. Pesticide Biochemistry and Physiology 111: 7-13.

Sasaki, Y.; Nagano, Y. 2004. Plant acetyl-CoA carboxylase: structure, biosynthesis, regulation, and gene manipulation for plant breeding. Bioscience, Biotechnology, and Biochemistry 68: $1175-1184$.

Scarabel, L.; Panozzo, S.; Savoia, W.; Sattin, M. 2014. Target-site ACCase-resistant johnsongrass (Sorghum halepense) selected in summer dicot crops. Weed Technology 28: 307-315.

Scarabel, L.; Panozzo, S.; Varotto, S.; Sattin, M. 2011. Allelic variation of the ACCase gene and response to ACCaseinhibiting herbicides in pinoxaden-resistant Lolium spp. Pest Management Science 67: 932-941.

Shaner, D.L. 2014. Herbicide Handbook. Weed Sc ience Society of America, Champaign, IL, USA.

Shergill, L.S.; Malone, J.; Boutsalis, P.; Preston, C.; Gill, G. 2017. Basis of ACCase and ALS inhibitor resistance in Hordeum glaucum Steud. Pest Management Science 73: 1638-1647.

Shorrosh, B.S.; Dixon, R.A.; Ohlrogge, J.B. 1994. Molecular cloning, characterization, and elicitation of acetyl-CoA carboxylase from alfalfa. Proceedings of the National Academy of Sciences of the United States of America 91: 4323-4327.

Takano, H.K.; Melo M.S.C.; Ovejero R.F.L.; Westra P.H.; Gaines T.A.; Dayan F.E. 2020. Trp2027Cys mutation evolves in Digitaria insularis with cross-resistance to ACCase inhibitors. Pesticide Biochemistry and Physiology doi:https://doi.org/10.1016/j. pestbp.2019.12.011.

Takano, H.K.; Mendes, R.R.; Scoz, L.B.; Ovejero, R.F.L.; Constantin, J.; Gaines, T.A.; Westra, P.; Dayan, F.E.; Oliveira, R.S. 2019a. Proline-106 EPSPS mutation imparting glyphosate resistance in goosegrass (Eleusine indica) emerges in South America. Weed Science 67: 48-56.

Takano, H.K.; Oliveira Jr, R.S.; Constantin, J.; Silva, V.F.V.; Mendes, R.R. 2018. Chemical control of glyphosate-resistant goosegrass. Planta Daninha 36: e018176124.

Takano, H.K.; Patterson, E.L.; Nissen, S.J.; Dayan, F.E.; Gaines, T.A. 2019b. Predicting herbicide movement across semipermeable membranes using three phase partitioning. Pesticide Biochemistry and Physiology 158: 1-5.

Tester, M.; Langridge, P. 2010. Breeding technologies to increase crop production in a changing world. Science 327: 818-822.

Thill, D.C.; Joan, M.L.; Robert, H.C.; Edward, J.B. 1991. Integrated weed management: a component of integrated pest management; a critical review. Weed Technology 5: 648-656.

Vidal, R.A.; Fleck, N.G. 1997. The risk of finding herbicide resistant weed biotypes. Planta Daninha 31: 887-892 (in Portuguese, with abstract in English). 
Walsh, M.J.; Broster, J.C.; Schwartz-Lazaro, L.M.; Norsworthy, J.K.; Davis, A.S.; Tidemann, B.D.; Beckie, H.J.; Lyon, D.J.; Soni, N.; Neve, P.; Bagavathiannan, M.V. 2018. Opportunities and challenges for harvest weed seed control in global cropping systems. Pest Management Science 74: 2235-2245.

Xia, X.; Tang, W.; He, S.; Kang, J.; Ma, H.; Li, J. 2016. Mechanism of metamifop inhibition of the carboxyltransferase domain of acetyl-coenzyme A carboxylase in Echinochloa crus-galli. Scientific Reports 6: 340-366.

Xu, H.; Li, J.; Zhang, D.; Cheng, Y.; Jiang, Y.; Dong, L. 2014. Mutations at codon position 1999 of acetyl-CoA carboxylase confer resistance to ACCase-inhibiting herbicides in Japanese foxtail (Alopecurus japonicus). Pest Management Science 70: 1894-1901.

Yu, L.P.C.; Kim, Y.S.; Tong, L. 2010. Mechanism for the inhibition of the carboxyltransferase domain of acetyl-coenzyme A carboxylase by pinoxaden. Proceedings of the National Academy of Sciences of the United States of America 107: 7277.

Yu, Q.; Collavo, A.; Zheng, M.-Q.; Owen, M.; Sattin, M.; Powles, S.B. 2007. Diversity of acetyl-coenzyme A carboxylase mutations in resistant Lolium populations: evaluation using clethodim. Plant Physiology 145: 547-558.
Yu, Q.; Powles, S. 2014. Metabolism-based herbicide resistance and cross-resistance in crop weeds: a threat to herbicide sustainability and global crop production. Plant Physiology 166: 1106-1118.

Zhang, H.; Tweel, B.; Tong, L. 2004. Molecular basis for the inhibition of the carboxyltransferase domain of acetylcoenzyme-A carboxylase by haloxyfop and diclofop. Proceedings of the National Academy of Sciences of the United States of America 101: 5910-5915.

Zhang, H.; Yang, Z.; Shen, Y.; Tong, L. 2003. Crystal structure of the carboxyltransferase domain of acetyl-coenzyme A carboxylase. Science 299: 2064-2067.

Zhu, X.L.; Zhang, L.; Chen, Q.; Wan, J.; Yang, G.F. 2006. Interactions of aryloxyphenoxypropionic acids with sensitive and resistant acetyl-coenzyme a carboxylase by homology modeling and molecular dynamic simulations. Journal of Chemical Information and Modeling 46: 1819-1826. 